\title{
Evaluation of Antidiarrheal Activity of Aqueous Leaf Extract of Anogeissus leiocarpus on Castor Oil-Induced Diarrhea in Rats
}

\author{
Michel Archange Fokam Tagne ${ }^{1 *}$, Yaouke Rékabi ${ }^{1}$, Paul Aimé Noubissi ${ }^{2}$, Gaëtan Olivier \\ Fankem ${ }^{3}$, Hypolyte Akaou ${ }^{1}$, Henri Wambe ${ }^{4}$ and René Kamgang ${ }^{3,5}$ \\ ${ }^{1}$ Department of Biological Science, University of Ngaoundéré, Cameroon
}

${ }^{2}$ Department of Zoology and Animal Physiology, University of Buea, Cameroon

${ }^{3}$ Animal Physiology Laboratory, University of Yaoundé I, Cameroon

${ }^{4}$ Department of Biological Science, University of Dschang, Cameroon

${ }^{5}$ Laboratory of Endocrinology and Radioisotopes, Institute of Medical Research and Medicinal Plants studies (IMPM), Cameroon

*Corresponding author: Michel Archange Fokam Tagne, Department of Biological Science, Faculty of Science, University of Ngaoundéré, Cameroon, P.O. Box 454, Ngaoundéré, Cameroon.

To Cite This Article: Fokam Tagne et al. Evaluation of Antidiarrheal Activity of Aqueous Leaf Extract of Anogeissus leiocarpus on Castor OilInduced Diarrhea in Rats. Am J Biomed Sci \& Res. 2019 - 3(1). AJBSR.MS.ID.000629. DOI: 10.34297/AJBSR.2019.03.000629

Received: May 01, 2019 | Published: May 15, 2019

\begin{abstract}
Diarrheal diseases are a major public health problem in developing countries. Anogeissus leiocarpus (DC.) Gill. \& Perr (Combretaceae) is used in Africa and particularly in Cameroon for the empirical treatment of diarrhea. The present study was undertaken to evaluate the effects of aqueous extract of leaves of Anogeissus leiocarpus on castor oil-induced diarrhea in rats. Diarrhea was induced by administering $10 \mathrm{~mL} / \mathrm{kg}$ body weight of castor oil orally to male rats. The determination of effective doses was made by assessing the weight and frequency of diarrheal stool of different doses of the extract (25 mg/kg, $50 \mathrm{mg} / \mathrm{kg}, 100 \mathrm{mg} / \mathrm{kg}, 200 \mathrm{mg} / \mathrm{kg}$ and $400 \mathrm{mg} / \mathrm{kg}$ ). The effects of the aqueous extract of Anogeissus leiocarpus on intestinal transit were determined with an activated charcoal meal in rats. The effects of the aqueous extract of Anogeissus leiocarpus on intestinal secretion were evaluated by measuring the volume of the intestinal content and by dosing the electrolytes $\left(\mathrm{Na}^{+}, \mathrm{K}^{+}\right.$and $\left.\mathrm{Cl}\right)$ in the intestinal content by the colorimetric method.

Castor oil-induced diarrhea was significantly inhibited ( $\mathrm{P}<0.01$ ) by $59.93 \% ; 69.39 \% ; 68.88 \% ; 67.60 \%$ and $75.00 \%$, respectively in the animals treated with the aqueous extract of the leaves of Anogeissus leiocarpus at doses of $25 \mathrm{mg} / \mathrm{kg}, 50 \mathrm{mg} / \mathrm{kg}, 100 \mathrm{mg} / \mathrm{kg}, 200 \mathrm{mg} / \mathrm{kg} \mathrm{and} 400 \mathrm{mg} / \mathrm{kg}$. The intestinal transit was inhibited significantly ( $\mathrm{P}<0.01$ ) by $29.34 \%, 31.35 \%$ and $43.29 \%$, respectively of the aqueous extract of $A$. leiocarpus at doses $25 \mathrm{mg} / \mathrm{kg}, 50 \mathrm{mg} / \mathrm{kg}$ and $100 \mathrm{mg} / \mathrm{kg}$. The volume of the intestinal content was decreased significantly (P <0.01) by $53.91 \%, 83.43 \%$ and $72.17 \%$, respectively in the animals treated with the extract at doses $25 \mathrm{mg} / \mathrm{kg}, 50 \mathrm{mg} / \mathrm{kg}$ and $100 \mathrm{mg} / \mathrm{kg}$ as well as the concentration of electrolytes. These results would justify the use of leaves of Anogeissus leiocarpus in the treatment of diarrhea in traditional medicine.
\end{abstract}

Keywords: Anogeissus leiocarpus; Diarrhea; Castor oil; Male rat

\section{Introduction}

Diarrheal diseases are a major public health problem in developing countries [1,2]. Diarrhea is intestinal disorders characterized by the passage of three or more loose and/or liquid stools daily and is one of the leading causes of mortality and morbidity in developing countries $[3,4]$. The pathophysiology of diarrhea is due to increased secretion and decreased fluid absorption leading to increased fluidity, stool volume and frequency, excessive loss of body water and electrolytes [5]. According to the WHO [6], there are approximately 2 billion cases of diarrhea per year worldwide. It is the leading cause of death for children under five (05) with about 1.5 million children each year [7], the third leading cause of death among infectious diseases at all ages [8,9], and the fifth leading cause of premature death worldwide [6]. The probability of developing diarrhea is $39.1 \%$ for an inhabitant of sub-Saharan Africa, compared with $7.2 \%$ in developed countries [10]. In Cameroon, the prevalence of diarrhea is $18.9 \%$, with about $19.7 \%$ in rural 
areas [11]. The management of diarrheal diseases is very expensive and varies from CFAF 1.6 billion per year for clinical consultation services to CFAF 2.6 billion for hospitalizations [12]. In addition, synthetic chemicals such as diphenoxylate, loperamide and antibiotics used in the treatment of diarrheal diseases have harmful side effects for the body [13].

To cope with the damage caused by diarrhea in developing countries, a diarrhea program has been put in place the World Health Organization (WHO) which involves the use of traditional medicinal plants [4]. Many hopes remain hidden in the secrets of medicinal plants and according to WHO, in 2013, more than $80 \%$ of African populations use traditional medicine and pharmacopoeia to deal with health problems $[14,15]$. More than two-thirds $(2 / 3)$ of the world's medicinal plant species are found in tropical Africa $[14,15]$. Some of these plants are used in the treatment of diarrheal diseases. We can mention among others: Zygophyllum gaetulum [16], Erythrina senegalensis [17], Pterocarpus erinaceus [18], Holarrhenna antidysenterica [19], Oxalis barrelieri [20]. In Cameroon, maceration of the leaves of Anogeissus leiocarpus is used empirically for diarrheal diseases or dysentery treatment [21]. Anogeissus leiocarpus (DC.) Guill. and Perrot, belonging to the Combretaceae family, is a deciduous tree species up to 15 to $18 \mathrm{~m}$ tall and up to $1 \mathrm{~m}$ in diameter. It grows in dry forests and the forest gallery $[22,23]$. Anogeissus leiocarpus is used for the treatment of malaria [24], helminthiasis [25], leishmaniasis [26] and trypanosomiasis [26] in Ivory Cost and in Nigeria. The extract of this plant is a powerful antioxidant and hepatoprotective [27-29]. The preliminary phytochemical screening of stem and bark extracts of Anogeissus leiocarpus shows the majority of secondary metabolites consisting of tannins, flavonoids, terpenes and saponins [21,30]. No scientific work has so far evaluated the antidiarrheal activity of this plant. The main objective of this work is to evaluate the activities of Anogeissus leiocarpus leaves aqueous extract on castor oil-induced diarrhea in rats.

\section{Material and Methods}

\section{Plant material}

Fresh leaves of Anogeissus leiocarpus were collected between 8:00 and 10:00 AM in Mban-Rey (Northern Region of Cameroon) in June 2018 and identified in the Department of Biological Sciences, Faculty of Science of University of Ngaoundere Cameroon by Professor Pierre Marie Mapongmetsem. The leaves of Anogeissus leiocarpus were washed with water, shade-dried and crushed. The powder $(180 \mathrm{~g})$ was macerated in distilled water $(1.8 \mathrm{~L})$ for $72 \mathrm{~h}$. After a maceration period, this was then filtered with Whatman No. 3 filter paper and the filtrate was frozen at $-35^{\circ} \mathrm{C}$ and then lyophilized with the freeze-dryer (CHRIST, ALPHA 1-2. LD. plus) to yield $29.14 \mathrm{~g}(16.19 \%)$ of greenish-colored extract.

\section{Experimental Animals}

The experimental animals were male Wistar albino rats $(90-$ $160 \mathrm{~g}$ ), 8 to 12 weeks old. Before the experiment, these rats were acclimated to the Laboratory of Medicinal Plants, Health and Galenic Formulation of the Department of Biological Sciences of University of Ngaoundere for three weeks in the laboratory environmental conditions $\left(24{ }^{\circ} \mathrm{C}-26{ }^{\circ} \mathrm{C}\right.$ and $12 \mathrm{~h}$ light $/ 12 \mathrm{~h}$ darkness). Experiments on animals have been carried out according to the European Union guidelines on animal care (EEC Council No. 86/609) [31] adopted in Cameroon by its Ministry of Scientific Research and Innovation. Rats housed in metabolic cage and their diet consisted of a mixture of corn flour (60\%), palm oil (3\%), fish meal (12\%), soy flour (15\%) and a little salt that is in granule form [32].

\section{Castor oil-induced diarrhea test in rat}

Thirty-five (35) male Wistar albino rats (90-160g) divided into seven (7) groups of five (5) animals each were fasted for eighteen (18h) with free access to water before the start of the experiment. To induce the diarrhea, castor oil was given per os $(10 \mathrm{~mL} / \mathrm{kg} \mathrm{bw})$ to all animals. After diarrheal induction, each animal was placed individually in cages lined with wathman No 3-filter paper. Thirty (30) minutes later, animals from diarrheal control (DC) group received distilled water $(10 \mathrm{~mL} / \mathrm{kg} \mathrm{bw})$, animals from treated control group (Lop5) received loperamide (MH/DRUGS/KD-699, PALGHAI 401-404) (5 mg/kg bw) and animals from five test groups received one of the aqueous leaf extract of Anogeissus leiocarpus at doses 25 (AlAE25); 50 (AlAE50); 100 (AlAE100); 200 (AlAE200) or 400 (AlAE400) $\mathrm{mg} / \mathrm{kg}$ bw orally. The filter paper was changed every hour for 5 hours. Every hour, the stools were removed and weighed [33]. The number and mass of diarrheal and total stools were recorded. The stool emission frequency (SEF) and the percentage inhibition (I) of diarrhea in each group of treated animals were calculated respectively according to the following formulas:

$$
\begin{aligned}
& \text { SEF }=\frac{\text { Total Number of Stool }}{\text { Time }(5 h)} \\
& I(\%)=\frac{(S M D C-S M D T)}{\text { SMDC } \times 100}
\end{aligned}
$$

Where, SEF: Stool Emission Frequency, I: Inhibition; SMDC: Stool Mass of Diarrheal Control, SMDT: Stool Mass of Diarrheal Test.

\section{Gastrointestinal motility test in rat}

Five (05) groups of five (05) rats each were fasted for eighteen (18) hours with free access to water before the start of the experience. After the fasting period, all animals were weighted, animals in the normal control (NC) group received distilled water $(10 \mathrm{~mL} /$ $\mathrm{kg}$ bw), animals in the treated control group (AT0.3) received Atropine sulfate (Yanzhou Xierkangtai Pharma.Co., Ltd., Jiuguan Bei, Yanzhou, PR China) $0.3 \mathrm{mg} / \mathrm{kg}$ ip, and the animals in the test groups received orally one of the aqueous extract doses of Anogeissus leiocarpus $25 \mathrm{mg} / \mathrm{kg}$ (AlAE25); $50 \mathrm{mg} / \mathrm{kg}$ (AlAE50) or $100 \mathrm{mg} / \mathrm{kg}$ (AlAE100) respectively. Thirty (30) minutes after administration of these treatments, each animal received orally $2 \mathrm{~mL}$ of charcoal meal ( $5 \%$ activated charcoal by $5 \%$ gum acacia) as peristaltic marker. Thirty (30) minutes later the animals were sacrificed by cervical dislocation and the abdomen was opened using forceps. The intestine was removed, the total length of the small intestine (TLSI), and the distance covered by the charcoal meal in the small intestine (DCCM) were measured. The peristaltic index (PI) was calculated by the following formula $[4,34,35]$ : 


$$
P I=\frac{D C C M}{T L S I} * 100
$$

Where: DCCM: Distance Covered by a Charcoal Meal in the small intestine; TLSI: Total Length of the Small Intestine.

The inhibition was determined by the following formula:

$$
I(\%)=\frac{(P I c-P I t)}{P I c} * 100
$$

Where, PIc: Peristaltic Index in the normal Control; PIt: Peristaltic Index in the Test Group.

\section{Castor oil-induced interopooling test in rats}

Six (6) groups of five (5) rats each fasted for eighteen (18) hours with free access to water were used. After fasting period, all animals were weighted, animals in the normal control (NC) and diarrheal control (DC) groups received orally distilled water $(10 \mathrm{~mL} /$ $\mathrm{kg} \mathrm{bw}$ ), the animals in the treated control group (Lop5) received loperamide ( $5 \mathrm{mg} / \mathrm{kg} \mathrm{bw}$ ), and the animals of the test groups, respectively received one of the doses of Anogeissus leiocarpus aqueous extract $25 \mathrm{mg} / \mathrm{kg}$ (AlAE25); $50 \mathrm{mg} / \mathrm{kg}$ (AlAE50) or $100 \mathrm{mg} /$ $\mathrm{kg}$ (AlAE100). Thirty (30) minutes after treatment, each animal received orally castor oil (10 $\mathrm{mL} / \mathrm{kg} \mathrm{bw})$, with the exception of animals in the normal control (NC) group. An hour later, the animals were sacrificed by cervical dislocation, the abdomen was opened, the small intestine (from the pylorus to the caecum) was removed, weighed, and its content was emptied into a graduated tube, and finally the gut was weighed $[18,33,36,37]$. The volume of intestinal contents was measured and stored in the fridge for sodium ion $\left(\mathrm{Na}^{+}\right)$, potassium ion $\left(\mathrm{K}^{+}\right)$and chloride ion $\left(\mathrm{Cl}^{-}\right)$measurements, and the determination of the osmotic gap. The inhibition was determined by the following formula:

$$
I(\%)=\frac{V I C D C-V I C T G}{\mathrm{VICDC}} * 100
$$

Where, VICDC: Volume of Intestinal Content of Diarrheal Control; VICTG: Volume of Intestinal Content of Test Group.

Sodium ion $\left(\mathrm{Na}^{+}\right)$, potassium ion $\left(\mathrm{K}^{+}\right)$, and chloride ion $\left(\mathrm{Cl}^{-}\right)$ measurements were made using the colorimetric method using the kits [(LIQUIZYME SODIUM, BEACON DIAGNOSTIICS PVT.LTD., 424, NEW GIDC, KABILPORE, NAVSARI-396 424. INDIA); (LIQUIZYME POTASSIUM, BEACON DIAGNOSTIICS PVT.LTD., 424, NEW GIDC, KABILPORE, NAVSARI-396 424. INDIA); (SGM Italia-Via Pindaro 28C-Roma), respectively], according to the manufacturer's protocol. The osmotic gap was calculated according to the formula:

$$
O G=290-2 X\left(\left[\mathrm{Na}^{+}\right]+\left[\mathrm{K}^{+}\right]\right)[38](6)
$$

\section{Statistical analysis}

Datas were expressed as mean \pm SEM. Statistical significance was determined by the one-way analysis of variance (ANOVA) followed by Dunnett's test using the software Graph Pad in Stat. Differences were considered significant at $\mathrm{p}<0.05$.

\section{Results}

\section{Effects of Anogeissus leiocarpus leaves aqueous extract on stool frequencies and mass in rats}

After castor oil administration, the animals became calm, less mobile and folded themselves with erect hairs. Diarrheal animals treated with different doses of the extract and loperamide gradually regained their mobility during treatment. The first diarrheal stool usually appeared in the first hour and rarely in the second hour of treatment. These stools were either pasty, liquid (diarrhea stool) or molded (normal stool) (Figure 1).

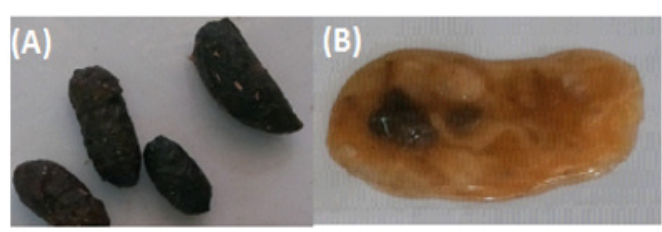

\begin{tabular}{|c|c|c|c|c|}
\hline Group & $\operatorname{DSF}(\mathrm{N} / \mathrm{h})$ & TSF (N/h) & DSM (g) & TSM (g) \\
\hline DC & $4.2 \pm 0.38$ & $9.00 \pm 1.05$ & $2.35 \pm 0.39$ & $3.55 \pm 0.67$ \\
\hline Lop5 & $1.60 \pm 0.93^{*}$ & $2.60 \pm 0.68^{* *}$ & $0.84 \pm 0.37 *$ & $1.15 \pm 0.24^{* *}$ \\
\hline AlAE25 & $0.95 \pm 0.32^{* *}$ & $1.80 \pm 0.37^{* *}$ & $0.95 \pm 0.31^{*}$ & $1.06 \pm 0.30^{* *}$ \\
\hline AlAE50 & $1.80 \pm 0.80^{*}$ & $3.00 \pm 1.67^{* *}$ & $0.72 \pm 0.39 *$ & $0.98 \pm 0.55^{* *}$ \\
\hline AlAE100 & $1.20 \pm 0.59^{*}$ & $2.60 \pm 1.08^{* *}$ & $0.73 \pm 0.35^{*}$ & $1.04 \pm 0.44^{* *}$ \\
\hline AlAE200 & $1.80 \pm 0.92^{*}$ & $3.00 \pm 1.76^{* *}$ & $1.35 \pm 0.73^{*}$ & $0.40 \pm 0.51^{* *}$ \\
\hline AlAE400 & $0.80 \pm 0.38^{* *}$ & $1.40 \pm 0.60^{* *}$ & $0.59 \pm 0.25^{* *}$ & $0.79 \pm 0.35^{* *}$ \\
\hline
\end{tabular}

Figure 1: Stool appearance after induction of diarrhea and during treatment (A) Normal stool; (B) Diarrheal stool.

Table 1: Effects of Anogeissus leiocarpus leaves aqueous extract on stool frequencies and on stool mass in rats.

Data are mean \pm S.E.M ( $\mathrm{n}=5)$. DC: diarrheal control; Lop5: Loperamide $5 \mathrm{mg} / \mathrm{kg}$; AIAE25: A. leiocarpus aqueous extract 25 mg/kg; AIAE50: A. leiocarpus aqueous extract $50 \mathrm{mg} / \mathrm{kg}$; AIAE100: A. leiocarpus aqueous extract $100 \mathrm{mg} / \mathrm{kg}$; AlAE200: A. leiocarpus aqueous extract $200 \mathrm{mg} / \mathrm{kg}$; AlAE400: A. leiocarpus aqueous extract $400 \mathrm{mg} / \mathrm{kg}$; DSF: Diarrheal stool frequency, TSF: Total Stool Frequency, DSM: Diarrheal Stool Mass, TSM: Total Stool Mass.

Significant difference: * $\mathrm{P}<0.05,{ }^{* *} \mathrm{P}<0.01$ vs $\mathrm{DC}$. 
Five (5) hours after diarrheal induction, diarrheal control emitted $2.35 \pm 0.39 \mathrm{~g}$ stool with a frequency of $4.20 \pm 0.38$ stools/hour. Different doses of aqueous extract of $A$. leiocarpus reduced significantly $(\mathrm{P}<0.01)$ the number and mass of diarrheal stools in the treated animals. The frequencies of these diarrheal stools were: $4.20 \pm 0.38,1.60 \pm 0.93,0.95 \pm 0.32,1.80 \pm 0.80,1.20 \pm 0.59,1.80 \pm 0.92$, and $0.80 \pm 0.38$ stool/h, respectively, in diarrheal controls, lopera- mide-treated rats, and rats treated with $A$. leiocarpus aqueous extract at doses of 25, 50, 100, 200 and $400 \mathrm{mg} / \mathrm{kg}$ bw (Table 1).

The inhibition rate of diarrheal stool mass was significant ( $\mathrm{P}<0.01$ ): 65.14\%, 59.93\%, 69.39\%, 68.88\%, 67.60\% and $75.00 \%$ respectively for Lop5, AlAE25, AlAE50, AlAE100, AlAE200 and AlAE400 (Figure 2).

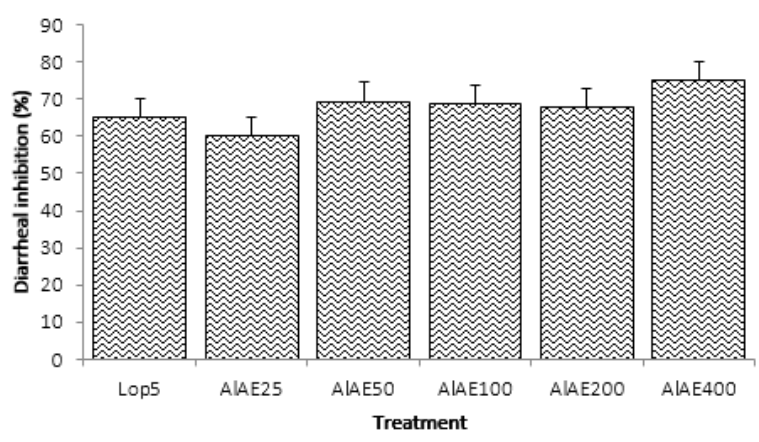

Data are mean \pm S.E.M $(n=5)$. Lop5: Loperamide $5 \mathrm{mg} / \mathrm{kg}$; AIAE25: A. leiocarpus aqueous extract $25 \mathrm{mg} / \mathrm{kg} ;$ AlAE50: A. leiocarpus aqueous extract $50 \mathrm{mg} / \mathrm{kg}$; AIAE100: A. leiocarpus aqueous extract $100 \mathrm{mg} / \mathrm{kg}$; AIAE200: A. leiocarpus aqueous extract 200 mg/kg; AlAE400: A. leiocarpus aqueous extract $400 \mathrm{mg} / \mathrm{kg}$.

Figure 2: Diarrheal inhibition in treated animals.

\section{Effect of Anogeissus leiocarpus leaves aqueous extract on intestinal transit in rats}

Table 2: Effects of Anogeissus leiocarpus leaves aqueous extract on intestine transit in normal rats.

\begin{tabular}{|c|c|c|c|c|}
\hline Group & TLSI $(\mathrm{cm})$ & LTCM $(\mathrm{cm})$ & PI (\%) & I (\%) \\
\hline NC & $88.20 \pm 7.94$ & $75.10 \pm 6.57$ & $85.41 \pm 2.90$ & 42.13 \\
\hline AT0.3 & $104.00 \pm 2.02$ & $51.39 \pm 1.76$ & $49.42 \pm 1.63^{* *}$ & 29.34 \\
\hline AlAE25 & $92.40 \pm 0.97$ & $55.76 \pm 3.15$ & $60.35 \pm 3.18^{* *}$ & 31.35 \\
\hline AlAE50 & $95.40 \pm 3.89$ & $55.93 \pm 4.81$ & $58.63 \pm 4.70^{* *}$ & 43.29 \\
\hline AlAE100 & $96.00 \pm 2.57$ & $46.49 \pm 1.80$ & $48.43 \pm 1.94^{* *} \dot{\alpha}$ & \\
\hline
\end{tabular}

Values are expressed as mean \pm S.E.M $(\mathrm{n}=5)$. NC: normal control; AT0.3: Atropine sulfate $0.3 \mathrm{mg} / \mathrm{kg}$; AIAE25: A. leiocarpus aqueous extract $25 \mathrm{mg} / \mathrm{kg}$; AIAE50: A. leiocarpus aqueous extract $50 \mathrm{mg} / \mathrm{kg}$; AIAE100: A. leiocarpus aqueous extract $100 \mathrm{mg} / \mathrm{kg}$; TLSI: total length of small intestine, LTCM: length traveled by charcoal meal, PI: Peristaltic Index, I: Inhibition. Significant difference: ${ }^{*} \mathrm{P}<0.05$, ${ }^{* *} \mathrm{P}<0.01$ vs NC. àP $<0.05$ vs AT0.3.

The peristaltic index in normal control (NC) rats was $85.41 \pm 2.90 \%$. The atropine $(0.3 \mathrm{mg} / \mathrm{kg} \mathrm{bw}), 25,50$ and $100 \mathrm{mg} /$ $\mathrm{kg}$ bw $A$. leiocarpus aqueous extract significantly $(\mathrm{p}<0.01)$ inhibit-

ed the normal propulsion respectively: $-42.13 \%,-29.34 \%,-31.35 \%$ and $-43.29 \%$ (Table 2).

\section{Effects of Anogeissus leiocarpus leaves aqueous extract on intestinal secretion in rats}

Table 3: Effects of Anogeissus leiocarpus leaves aqueous extract on castor oil-induced enteropooling in male rats.

\begin{tabular}{|c|c|c|c|c|c|}
\hline Group & VIC (mL) & MUSI (g) & MESI (g) & MD (g) & I $(\%)$ \\
\hline $\mathrm{NC}$ & $0.46 \pm 0.07^{* *}$ & $4.51 \pm 0.20^{* *}$ & $3.37 \pm 0.14^{* *}$ & $1.14 \pm 0.12^{* *}$ & \\
\hline DC & $2.30 \pm 0.23 \mathrm{~b} \beta$ & $6.71 \pm 0.24 b$ & $4.27 \pm 0.22 b$ & $2.44 \pm 0.28 b$ & \\
\hline Lop5 & $0.38 \pm 0.09^{* *}$ & $4.26 \pm 0.17^{* *}$ & $3.48 \pm 0.10^{* *}$ & $0.78 \pm 0.11^{* *}$ & $85.04 \%$ \\
\hline AlAE25 & $1.06 \pm 0.04^{* *} \mathrm{~b} \beta$ & $5.41 \pm 0.26^{* *} \mathrm{a}$ & $3.96 \pm 0.10 \mathrm{a}$ & $1.48 \pm 0.34^{*}$ & $53.91 \%$ \\
\hline AlAE50 & $038 \pm 0.06^{* *}$ & $4.34 \pm 0.10^{* *}$ & $3.66 \pm 0.09 *$ & $0.69 \pm 0.07^{* *}$ & $83.43 \%$ \\
\hline AlAE100 & $0.66 \pm 0.09^{* *}$ & $5.19 \pm 0.13^{* *}$ & $4.13 \pm 0.19 b$ & $1.06 \pm 0.16^{* *}$ & $72.17 \%$ \\
\hline
\end{tabular}

Data are mean \pm SEM. $(n=5)$. NC: Normal control; DC: diarrheal control; Lop5: Loperamide 5 mg/kg; AlAE25: A. leiocarpus aqueous extract $25 \mathrm{mg} /$ $\mathrm{kg}$; AIAE50: A. leiocarpus aqueous extract $50 \mathrm{mg} / \mathrm{kg}$; AIAE100: A. leiocarpus aqueous extract $100 \mathrm{mg} / \mathrm{kg}$; VIC: Volume of intestinal content; MUSI: Mass of untrimmed small intestine; MESI: Mass of empty small intestine; MD: Mass difference; I: Inhibition. Significant difference: ${ }^{*} P<0.05$; ${ }^{* *} P<0.01$ vs $\mathrm{DC} ; \mathrm{aP}<0.05 ; \mathrm{bP}<0.01$ vs NC; 
Volumes of intestinal contents were $0.46 \mathrm{~mL}, 2.3 \mathrm{~mL}, 0.38 \mathrm{~mL}$, $1.06 \mathrm{~mL}, 0.38 \mathrm{~mL}$ and $0.66 \mathrm{~mL}$, respectively in normal control group (NC), diarrheal control (DC) group, the rats treated with loperamide $5 \mathrm{mg} / \mathrm{kg}$ (Lop5) and the test groups treated with $A$. leiocarpus aqueous extract at doses $25 ; 50$ and $100 \mathrm{mg} / \mathrm{kg}$ bw. The mass difference between the untrimmed small intestine and the empty small intestine were $1.14 \pm 0.12 \mathrm{~g}, 2.44 \pm 0.28 \mathrm{~g}, 0.78 \pm 0.11 \mathrm{~g}, 1.48 \pm 0.34 \mathrm{~g}$, $0.69 \pm 0.07 \mathrm{~g}$, and $1.06 \pm 0.16 \mathrm{~g}$, respectively in normal control group (NC), diarrheal control (DC) group, the loperamide-treated group (Lop5) and the test groups treated with $A$. leiocarpus aqueous extract at doses 25; 50 and $100 \mathrm{mg} / \mathrm{kg}$ bw. Inhibitions of secretion were $85.04 \%, 53.91 \%, 83.43 \%, 72.17 \%$ respectively in the animals treated with loperamide $5 \mathrm{mg} / \mathrm{kg}$ bw (Lop5), the test groups treated with A. leiocarpus aqueous extract at doses 25; 50 and $100 \mathrm{mg} /$ $\mathrm{kg}$ (Table 3).

\section{Activity of Anogeissus leiocarpus leaves aqueous extract on intestinal secretion the of electrolytes in rats}

The following electrolytes were measured in the contents of the small intestine: sodium ions, potassium ions and chloride ions.
In diarrheal control, sodium ion concentration was $132.03 \pm 2.59$ $\mathrm{mEq} / \mathrm{L}$. These sodium ions decreased significantly $(\mathrm{P}<0.01)$ in the animals treated with the aqueous extract of the leaves of Anogeissus leiocarpus and were $92.61 \pm 2.58 \mathrm{mEq} / \mathrm{L}, 98.24 \pm 7.54 \mathrm{mEq} / \mathrm{L}$ and $108.92 \pm 3.07 \mathrm{mEq} / \mathrm{L}$, respectively, with the doses $25 \mathrm{mg} / \mathrm{kg}$ bw, 50 $\mathrm{mg} / \mathrm{kg}$ bw, and $100 \mathrm{mg} / \mathrm{kg}$ compared to animals treated with loperamide $(110.67 \pm 2.62 \mathrm{mEq} / \mathrm{L})$. The concentration of potassium ions was $7.69 \pm 1.81 \mathrm{mEq} / \mathrm{L}, 3.01 \pm 0.07 \mathrm{mEq} / \mathrm{L}, 5.94 \pm 0.29 \mathrm{mEq} / \mathrm{L}$, $3.33 \pm 0.10 \mathrm{mEq} / \mathrm{L}, 3.97 \pm 0.12 \mathrm{mEq} / \mathrm{L}$, and $6.19 \pm 0.12 \mathrm{mEq} / \mathrm{L}$, respectively in normal control group (NC), diarrheal control (DC) group, rats treated with loperamide (Lop5) and the test groups treated with $A$. leiocarpus aqueous extract at doses 25; 50 and $100 \mathrm{mg} / \mathrm{kg}$ bw. Concerning chloride ions, the concentration was $101.20 \pm 1.65$ $\mathrm{mEq} / \mathrm{L}, 109.80 \pm 0.04 \mathrm{mEq} / \mathrm{L}, 106.31 \pm 0.86 \mathrm{mEq} / \mathrm{L}, 104.43 \pm 0.29$ $\mathrm{mEq} / \mathrm{L}, 104.85 \pm 0.31 \mathrm{mEq} / \mathrm{L}$, and $105.11 \pm 0.04 \mathrm{mEq} / \mathrm{L}$, respectively in normal control group (NC), diarrheal control (DC) group, rats treated with loperamide (Lop5) and the test groups treated with A. leiocarpus aqueous extract at doses 25; 50 and $100 \mathrm{mg} / \mathrm{kg} \mathrm{bw}$ (Table 4).

\begin{tabular}{|c|c|c|c|}
\hline Table 4: Effects of Anogeissus leiocarpus leaves aqueous extract on concentration of electrolytes in the intestinal contents. & {$[\mathrm{Cl}] \mathrm{mEq} / \mathrm{L}$} \\
\hline Group & {$[\mathrm{Na}+] \mathrm{mEq} / \mathrm{L}$} & $7.69 \pm 1.81^{* *}$ & $101.20 \pm 1.65^{*}$ \\
\hline NC & $107.68 \pm 4.05^{* *}$ & $3.01 \pm 0.07$ & $109.80 \pm 0.04$ \\
\hline DC & $132.03 \pm 2.59$ & $5.94 \pm 0.29^{* *}$ & $106.31 \pm 0.86^{*}$ \\
\hline Lop5 & $110.67 \pm 2.62^{* *}$ & $3.33 \pm 0.10$ & $104.43 \pm 0.29^{*}$ \\
\hline AlAE25 & $92.61 \pm 2.58^{* *}$ & $3.97 \pm 0.12$ & $104.85 \pm 0.31^{*}$ \\
\hline AlAE50 & $98.24 \pm 7.54^{* *}$ & $6.19 \pm 0.12^{* *}$ & $105.11 \pm 0.04^{*}$ \\
\hline AlAE100 & $108.92 \pm 3.07^{* *}$ & & \\
\hline
\end{tabular}

Data are mean \pm S.E.M $(\mathrm{n}=5)$. NC: Normal control; DC: diarrheal control; Lop5: Loperamide $5 \mathrm{mg} / \mathrm{kg}$; AIAE25: A. leiocarpus aqueous extract $25 \mathrm{mg} / \mathrm{kg}$; AIAE50: A. leiocarpus aqueous extract $50 \mathrm{mg} / \mathrm{kg}$; AIAE100: A. leiocarpus aqueous extract $100 \mathrm{mg} / \mathrm{kg}$; [Na+]: Sodium ion concentration, [K+]: Potassium ion concentration, [Cl-]: Chloride ion concentration. Significant difference: ${ }^{*} \mathrm{P}<0.05$, ** $\mathrm{P}<0.01$ vs DC.

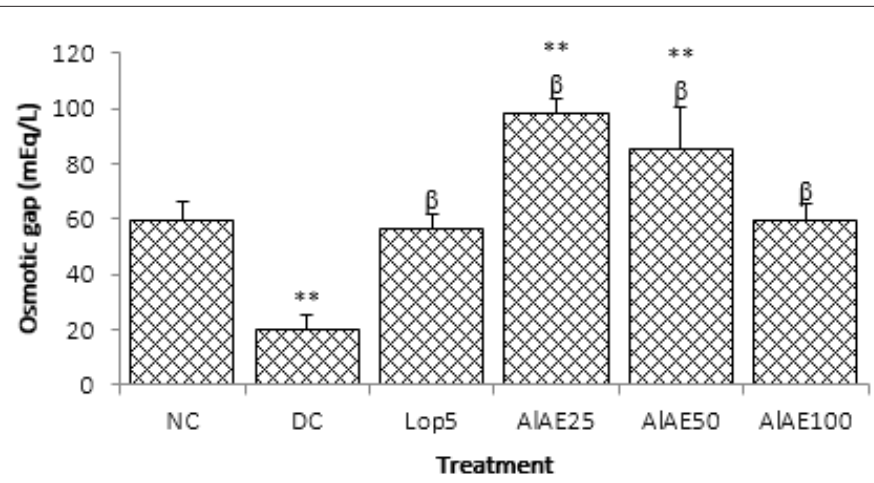

Data are mean \pm S.E.M $(\mathrm{n}=5)$. NC: Normal control; DC: diarrheal control; Lop5: Loperamide $5 \mathrm{mg} / \mathrm{kg}$; AlAE25: A. leiocarpus aqueous extract $25 \mathrm{mg} / \mathrm{kg}$; AIAE50: A. leiocarpus aqueous extract $50 \mathrm{mg} / \mathrm{kg}$; AIAE100: A. leiocarpus aqueous extract $100 \mathrm{mg} / \mathrm{kg}$. Significant difference: ${ }^{* *} \mathrm{P}<0.01 \mathrm{vs}$ normal control (NC); $\beta P<0.01$ vs diarrheal control (DC).

Figure 3: Osmotic gap in castor oil-induced diarrhea in rats.

The osmotic gap was 59.24, 19.91, 56.77, $98.11,85.58$ and 59.79 respectively in the normal control (NC), diarrheal control (DC), rats treated with loperamide $5 \mathrm{mg} / \mathrm{kg}$ bw (Lop5) and the test groups treated with A. leiocarpus aqueous extract at doses 25 (AlAE25); 50 (AlAE50) and 100 (AlAE100) mg/kg bw (Figure 3). 


\section{Discussion}

Diarrhea is defined as fecal urgency and incontinence associated with an imbalance between intestinal absorption and secretion mechanism often accompanied by hypermotility, resulting in excessive loss of water and electrolytes in the feces [39]. The study of the effect of aqueous extract of leaves of A. leiocarpus on experimental diarrhea induced by castor oil in rats showed a significant reduction in the number, the mass and frequency of diarrheal stools, an inhibition of the peristaltic index, a decrease in the volume of intestinal contents and the intestinal secretions of the electrolytes. Castor oil contains ricinoleic acid which stimulates intestinal peristalsis, stimulates gastrointestinal secretion and irritates the intestinal mucosa [5]. Ricinoleic acid also stimulates epithelial cells to produce nitric oxide and adenylate cyclase that lead to the production of prostaglandin-induced diarrhea [40]. Therefore, inhibition of prostaglandin biosynthesis is considered to inhibit ricinoleate-induced diarrhea [41]. The aqueous extract of Anogeissus leiocarpus leaves inhibited castor oil-induced diarrhea. These effects would be justified by the presence of compounds such as flavonoids, alkaloids [42] and tannins [21,30].

The extract also inhibited intestinal secretion as well as intestinal transit. Inhibition of intestinal transit by the extract was similar to that of atropine sulfate $0.3 \mathrm{mg} / \mathrm{kg}$. Atropine sulfate slows intestinal transit thanks to its anticholinergic effect which blocks the muscarinic receptor [43]. This extract, like Atropine, acts as a muscarinic antagonist by preventing the mobilization of $\mathrm{Ca}^{2+}$ ions responsible for muscle contraction $[44,45]$ by blocking the muscarinic receptors responsible for the formation of IP3, causing the increase in intracellular calcium [46]. It would also act, either by blocking the membrane calcium channels. The physiological consequence is the inhibition of intestinal peristalsis, which would increase the intestinal transit time [2]. The effect of $A$. leiocarpus aqueous extract on intestinal transit could then result from a partial capacity of the extract's antidiarrheal activity on muscarinic receptor function and/or possibly other mechanisms that would lead to the inhibition of intracellular calcium mobilization such as inhibition of IP3 and ricinoleic acid-induced prostaglandin in beaver oil.

Depending on the fecal osmotic gap, there are two types of diarrhea: secretory diarrhea so the osmotic gap is less than 50 $\mathrm{mEq} / \mathrm{L}$ and osmotic diarrhea so the osmotic gap is greater than 125 $\mathrm{mEq} / \mathrm{L}$. Normal values of fecal osmotic gap are between $50 \mathrm{mEq} / \mathrm{L}$ and $125 \mathrm{mEq} / \mathrm{L}[38,47]$. The fecal osmotic gap in diarrheal controls is less than $50 \mathrm{mEq} / \mathrm{L}$, which clearly shows that castor oil-induced diarrhea in rat is a good secretory diarrhea. However, in animals treated with the extract or the loperamide, the fecal osmotic gap is greater than $50 \mathrm{mEq} / \mathrm{L}$ and less than $100 \mathrm{mEq} / \mathrm{L}$. The aqueous extract of Anogeissus leiocarpus inhibits castor oil-induced diarrhea by inhibiting the secretion of water and electrolytes. Loperamide has an agonist action on $\mu$-receptors of opioid in the intestine $[48,49]$. Several published studies have clearly shown antisecretory action of loperamide via various mechanisms. Loperamide therefore binds not only to the opioid $\mu$ receptor but also to the $\delta$ receptor of the enterocyte. This results in a decrease in cAMP production in the epithelial cells of the intestine. This reduces hypersecretion of electrolytes in case of diarrhea $[48,49]$. In addition, loperamide inhibits the release of acetylcholine and prostaglandins since these two substances are known secretagogues (substances that, by stimulating cAMP, cause the secretion of ions) [48]. We can say that our extracts would act in the same mechanism to reduce or treat diarrhea by reducing the volume of the secretion of the intestinal continents and electrolytes.

\section{Conclusion}

From the results obtained, we can conclude that the aqueous extract of Anogeissus leiocarpus leaves has antidiarrheal properties by inhibiting intestinal peristalsis, gastrointestinal secretion of water and electrolytes. These results would justify the use of this plant in traditional medicine for the treatment of diarrhea.

\section{Acknowledgments}

Professor Njintang Yanou Nicolas is gratefully acknowledged for freeze-drying our extract.

\section{Conflicts of Interest}

No conflict of interest declared by the authors.

\section{References}

1. Broder MS, Chang E, Romanus D, Cherepanov D, Neary MP (2016) Healthcare and economic impact of diarrhea in patients with carcinoid syndrome. World J Gastroenterol 22: 2118-2125.

2. Faure C (2013) Role of Antidiarrhoeal drugs as adjunctive therapies for acute diarrhoea in children. Int J Pediatr p. 612403.

3. Casburn-Jones AC, Farthing MJG (2004) Management of infectious diarrhoea. Gut 53: 296-305.

4. Awe EO, Kolawole SO, Wakeel KO, Abiodun 00 (2011) Antidiarrheal activity of Pyrenacantha staudtii Engl. (Iccacinaceae) aqueous leaf extract in rodents. J Ethnopharmacol 137: 148-153.

5. Ezenwali M, Njoku O, Okoli C (2010) Studies on the anti-diarrheal properties of seed extract of Monodora tenuifolia. Int J Appl Res Nat Prod 2(4): 20-26.

6. World health statistics (2014) World Health Organization. Geneva, Switzerland.

7. Kent AJ, Banks MR (2010) Pharmacological management of diarrhea. Gastroenterol Clin North Am 39: 495-507.

8. Assogba AL, Ehui E, Maiga MF, Mibulumukini B, N’Dour CT, et al. (2012) L'Initiative contre les maladies Diarrhéiques et Entériques en Afrique: Une contribution à la lutte contre le choléra. Med Afr Noire 59(5): 251257

9. World health statistics (2011) World Health Organization. Geneva, Switzerland.

10. Fomekong F (2009) Influence du cadre et des conditions de vie des ménages sur la morbidité diarréique en milieu urbain camerounais. Le cas des villes de Yaoundé et de Douala. XXVIe Congrès Int. la Popul. Séance 207 Environ. santé. p. 15.

11. Yongsi HBN (2008) Pathogenic Microorganisms Associated With Childhood Diarrhea in Low-and-Middle Income Countries: Case Study of Yaoundé-Cameroon. Int J Environ Res Public Health 5(4): 213-229.

12. Aikins M, Armah G, Akazili J, Hodgson A (2010) Hospital health care cost of diarrheal disease in Northern Ghana. J Infect Dis 202: S126-S130.

13. Anup M, Saikat D, Subhash CM (2007) In Vivo Evaluation of Antidiarrhoeal Activity of the Seed of Swietenia macrophylla King (Meliaceae). Trop J Pharm Res 6: 711-716. 
14. Kolling M, Winkley K, Deden M Von (2010) Insights from Tanzania on diabetes health-seeking and medical pluralism among Dar es Salaam's urban poor. Global Health 6: 8-16.

15. Mangambu Mokoso J de D, Diggelen R Van, Mwanga Mwanga JC, Ntahobavuka H, Malaisse F, et al. (2012) Enthnobotanic survey of Pteridophytes, assessment of extinction risk and conservation strategies in the surroundings of the Kahuzi Biega National Park (DR Congo) Jean. Geo Eco Trop 36: 137-158.

16. El Cadi MA, Khabbal Y, Alaoui K, Faouzi M-A, Bruno E, et al. (2008) Antidiarrhoeal activity of Zygophyllum gaetulum. Phytothérapie 6: 2-4.

17. Otimenyin SO, Uzochukwu DC (2010) Spasmolytic and anti-diarrhea effects of the bark of Erythrina senegalensis and root of Kigelia Africana. Asian J Pharm Clin Res 3: 11-14.

18. Ezeja I, Ezeigbo I, Madubuike K, Udeh N, Ukweni I, et al. (2012) Antidiarrheal activity of Pterocarpus erinaceus methanol leaf extract in experimentally-induced diarrhea. Asian Pac J Trop Med 5: 147-150.

19. Sharma DK, Gupta VK, Kumar S, Joshi V, Mandal RSK, et al. (2015) Evaluation of antidiarrheal activity of ethanolic extract of Holarrhena antidysenterica seeds in rats. Vet World 8: 1392-1395.

20. Fokam Tagne MA, Noubissi PA, Fankem GO, Kamgang R (2018) Effects of Oxalis barrelieri L. (Oxalidaceae) aqueous extract on diarrhea induced by Shigella dysenteriae type 1 in rats. Heal Sci Reports 1: e20.

21. Salau A, Yakubu M, Oladiji A (2013) Cytotoxic activity of aqueous extracts of Anogeissus leiocarpus and Terminalia avicennioides root barks against Ehrlich Ascites Carcinoma cells. Indian J Pharmacol 45: 381-385.

22. Ouédraogo A, Kakaï RG, Thiombiano A (2013) Population structure of the widespread species, Anogeissus leiocarpa (DC.) Guill. \& Perr. across the climatic gradient in West Africa semi-arid area. South African J Bot South African Association of Botanists 88: 286-295.

23. Hennenberg KJ, Goetze D, Minden V, Traoré D, Porembski S (2005) Sizeclass distribution of Anogeissus leiocarpus (Combretaceae) along forestsavanna ecotones in northern Ivory Coast. J Trop Ecol 21: 273-281.

24. Akanbi OM, Omonkhua AA, Cyril-Olutayo CM, Fasimoye RY (2012) The antiplasmodial activity of Anogeissus leiocarpus and its effect on oxidative stress and lipid profile in mice infected with Plasmodium bergheii. Parasitol Res 110: 219-226.

25. Soro D, Koné WM, Bonfoh B, Dro B, Toily KB,et al. (2013) In vivo anthelmintic activity of Anogeissus leiocarpus Guill \& Perr (Combretaceae) against nematodes in naturally infected sheep. Parasitol Res 112: 2681-2688.

26. Shuaibu MN, Pandey K, Wuyep PA, Yanagi T, Hirayama K, et al. (2008) Castalagin from Anogeissus leiocarpus mediates the killing of Leishmania In Vitro. Parasitol Res 103: 1333-1338.

27. Barku VY, Opoku-Boahen Y, Owusu-Ansah E, Dayie NTKD, Mensah FE (2013) In-Vitro Assessment of Antioxidant and Antimicrobial Activities of Methanol Extracts of Six Wound Healing Medicinal Plants. J Nat Sci Res 3: 74-80.

28. Olajide O, Idowu D, Okolo S, Orishadipe A, Sunday T (2014) Phytochemical and antioxidant properties of some Nigerian medicinal plants. Am J Sci Ind Res 4: 328-332.

29. Atawodi SE, Adekunle 00, Bala I (2011) Antioxidant, organ protective and ameliorative properties of methanol extract of Anogeissus leiocarpus stem bark against carbon tetrachloride-induced liver injury. Int J Pharm Sci Res 2: 1443-1448.

30. Elegami AA, El-Nima EI, El Tohami MS, Muddathir AK (2002) Antimicrobial Activity of Some Species of the Family Combretaceae. Phyther Res 16: 555-561.

31. Smith J, van den Broek F, Martorel Jc, Hackbarth H, Ruksenas O, et al (2007) FELASA Working Grp, and Principles and Practice in Ethical
Review of Animal Experiments across Europe: Summary of the Report of a Felasa Working Group on Ethical Evaluation of Animal Experiments. Lab Anim 41: 143-160.

32. Kamgang R, Youmbi Mboumi R, Foyet Fondjo A, Fokam Tagne MA, Mengue N'dillé GPR, et al. (2008) Antihyperglycaemic potential of the water-ethanol extract of Kalanchoe crenata (Crassulaceae). J Nat Med 62: $34-40$.

33. Fokam Tagne MA, Kamgang R, Noubissi PA, Essame Oyono J-L (2015) Activity of Oxalis barrelieri aqueous extract on rat secretory diarrhea and intestine transit. J Appl Pharm Sci 5: 58-62.

34. Kamgang R, Fankem GO, Ngo Tetka J, Gonsu Kamga H, Fonkoua MC (2015) Antimicrobial and antidiarrheal effects of four Cameroon medicinal plants: Dichrocephala integrifolia, Dioscorea preusii, Melenis minutiflora, and Tricalysia okelensis. Int J Curr Pharm Res 7: 21-24.

35. Suleiman MM, Oyelowo BB, Abubakar A, Mamman M, Bello KT (2017) A controlled study to investigate anti-diarrhoeal effect of the stem-bark fractions of Terminalia avicennioides in laboratory animal models. Int J Vet Sci Med 5: 14-22.

36. Boominathan R, Devi B, Dewanjee S, Mandal S (2005) Studies on antidiarrhoeal activity of Ionodium suffruticosam ging. (violaceae) extract in rats. Recent Progress in Medicinal Plants. Phytotherapeutics 10: $375-380$.

37. Meite S, N'guessan JD, Bahi C, Yapi H, Djaman AJ (2009) Antidiarrheal Activity of the Ethyl Acetate Extract of Morinda morindoides in Rats. Trop J Pharm Res 8(3): 201-207.

38. Eherer AJ, Fordtran JS (1992) Fecal Osmotic Gap and pH in Experimental Diarrhea of Various Causes. Gastroenterology. Elsevier Inc 103(2): 545551.

39. Olatokunboh AO, Mofomosara SH, Anthony 0 (2010) Evaluation of the antidiarrhoeal effect of Lannea welwitschii Hiern (Anacardiaceae) bark extract. African J Pharm Pharmacol 4(4): 165-169.

40. Lakshminarayana M, Shivkumar H, Rimaben P, Bhargava V (2011) Antidiarrhoeal activity of leaf extract of Moringa Oleifera in experimentally induced diarrhoea in rats. Int J Phytomedicine 3(1): 6874.

41. Tunaru S, Althoff TF, Nüsing RM, Diener M, Offermanns S (2012) Castor oil induces laxation and uterus contraction via ricinoleic acid activating prostaglandin EP 3 receptors. PNAS Early Ed p. 1-6.

42. Abdullahi AL, Agho MO, Amos S, Gamaniel KS, Wambebe C (2002) Antidiarrhoeal activity of the aqueous extract of Terminalia avicennoides roots. Phyther Res 15(5): 431-434

43. Teixeira-Neto F, McDonell W, Black W, Harris W, Grovum L (2012) Effects of muscarinic receptor antagonists on acetylcholine-induced contractions of jejunal smooth muscle in horses. J Vet Pharmacol Ther 35: 313-318.

44. Johansen F, Massol R, Baker K, Fiebiger E, Blumberg RS, et al. (2012) Biology of Gut Immunoglobulins. In: Leonard R Johnson, Fayez K Ghishan, Jonathan D Kaunitz, Juanita L Merchant, Hamid M Said JDW, (Eds.), Physiol Gastron Tract, (5 ${ }^{\text {th }}$ edn.), Elsevier Inc p. 1089-118.

45. Bien J, Palagani V, Bozko P (2013) The intestinal microbiota dysbiosis and Clostridium difficile infection: is there a relationship with inflammatory bowel disease? Therap Adv Gastroenterol 6(1): 53-68.

46. Bordet R (2009) Le système cholinergique central: un acteur incontournable du traitement de la maladie d'Alzheimer. La Lett du Pharmacol 23: 63-70.

47. Gobert JG, Barbot L, Kapel N (2004) Digestive pathophysiology and fecal analysis. Ann Pharm Françaises 62: 367-370. 
48. Huijghebaert S, Awouters F, Tytgat GNJ (2003) Racecadotril Versus Loperamide: Antidiarrheal Research Revisited. Dig Dis Sci 48(2): 239250.
49. Hughes S, Higgs NB, Turnberg LA (1982) Antidiarrhoeal activity of loperamide: studies of its influence on ion transport across rabbit ileal mucosa In Vitro. Gut 23: 974-979. 